\title{
PENERAPAN MODEL PROBLEM SOLVING UNTUK MENINGKATKAN HASIL BELAJAR MATEMATIKA
}

\author{
Novi Dian Juniarti, Ndara Tanggu Renda \\ Jurusan PPG PGSD Prajabatan \\ Universitas Pendidikan Ganesha \\ Singaraja, Indonesia \\ e-mail: novidianjuniarti6@gmail.com, ndaratanggu.renda@undiksha.ac.id
}

\begin{abstract}
Abstrak
Penelitian ini dilatarbelakangi oleh rendahnya hasil belajar matematika siswa kelas 5 SD Negeri 4 Kampung Baru. Rendahnya hasil belajar matematika siswa disebabkan oleh rendahnya pemahaman siswa terhadap materi pelajaran yang disampaikan oleh guru. Dalam penyampaian materi, menggunakan model pembelajaran konvensional sehingga siswa kurang aktif dalam kegiatan pembelajaran. Adapun tujuan dilaksanakannya penelitian ini adalah untuk meningkatkan hasil belajar Matematika dengan menerapkan model problem solving pada siswa kelas V di SDN 4 Kampung Baru tahun pelajaran 2017/2018. Jenis penelitian ini adalah penelitian tindakan kelas (PTK). Penelitian ini terdiri dari 2 (dua) siklus dengan alur penyusunan yakni perencanaan tindakan, pelaksanaan tindakan, dan refleksi. Hasil penelitian menunjukkan bahwa pada siklus I rata-rata hasil belajar Matematika diperoleh sebesar 73,69. Selanjutnya, pada siklus II rata-rata hasil belajar Matematika diperoleh sebesar 80,22. Pada ketuntasan belajar siswa secara klasikal juga terjadi peningkatan, terlihat dari perhitungan ketuntasan belajar klasikal siklus 1 yakni 73,91\%, atau berkategori cukup dan siklus II 84,78 berkategori baik. Hai ini menunjukan baik dari rata-rata kelas maupun ktuntasan belajar klasikal siswa telah mencapai kriteria yang ditetapkan yaitu mencapai KKM 75 untuk rata-rata kelas dan prosentase $80 \%$ atau berkategori baik untuk ketutasan belajar klasikal. Berdasarkan hal tersebut dapat disimpulkan bahawa penggunaan model Problem Solving dapat meningkatkan hasil belajar matematika siswa kelas V SD Negeri 4 Kampung Baru Tahun 2017/ 2018.
\end{abstract}

Kata-kata Kunci : model, problem solving, hasil belajar Matematika.

\begin{abstract}
This research is motivated by the low of mathematics learning result of $5^{\text {th }}$ grade of SD Negeri 4 Kampung Baru. The low learning result of student math is caused by the low understanding of the students on the subject materials presented by the teacher. In the delivery of materials, using conventional model so that students are less active in learning activities. The purpose of this research is to improve the learning outcomes of Mathematics by applying problem solving model in $5^{\text {th }}$ grade students in SDN 4 Kampung Baru lesson year 2017/2018. This type of research is a classroom action research (PTK). This research consisted of 2 (two) cycles. Each cycle had stages including of action planning, implementation, observation, and reflection. This research used probblem solving model. The results showed that in cycle I the average learning outcomes obtained by Mathematics amounted to 73.69. Furthermore, in cycle II the average of mathematics learning result obtained by 80.22 . In the students' learning completeness classically also increased, seen from the calculation of classical learning completeness cycle 1 that is $73.91 \%$, or sufficient categorized and cycle II 84.78 categorized well. Hi this shows both the average class and completeness of classical score students have reached the established criteria of the reseach creteria (75) for the average grade and percentage of $80 \%$ or categorized well for the classical completeness. Based on it can be concluded that the use of Problem Solving model can improve the learning outcomes of students of $5^{\text {th }}$ grade SD Negeri 4 Kampung Baru Year 2017/2018
\end{abstract}

Key Word: models, Problem solving models, Mathematics Learning outcomes 


\section{Pendahuluan}

Pendidikan pada dasarnya merupakan usaha sadar yang dicanangkan untuk mengembangkan pengetahuan serta potensi dalam diri individu demi mencapai tujuan yang telah ditetapkan yakni meningkatkan sumber daya manusia dan mencetak generasi-generasi yang memiliki kepribadian baik, pengandalian diri, kecerdasan, akhlak mulia, serta keterampilan bagi dirinya, agama, dan Negaranya. Hal ini sejalan dengan tujuan pendidikan Nasional yakni mencetak insan Indonesia yang caerdas dan kompetitif (IICK).

"Matematika berkenaan dengan ide-ide/ konsep-konsep abstrak yang tersusun secara khirarkis dan penalarannya deduktif" (Hudojo, 1990:40). Kline (dalam Alkusaeri, 2013: 4) mengemukakan "Matematika bukanlah pengetahuan yang dapat sempurna karena dirirnya sendiri, tetapi keberadaannya untuk membantu manusia memahami, menguasai permasalahan sosial, ekonomi dan alam."berdasarkan pernyataan Kline tersebut, jelas bahwa Matematika bagi siswa SD sangat berguna untuk kepentingan hidup untuk menghadapi lingkungannya, untuk mengembangkan pola pikirnya, dan untuk mempelajari ilmu-ilmu dikemudian hari. Kegunaan atau manfaat Matematika bagi para siswa SD adalah sesuatu yang jelas dan tidak perlu dipersoalkan lagi, lebih-lebih pada era pengembangan ilmu pengetahuan dan teknologi dewasa ini. Oleh karena itu, guru diharapkan mampu menerapkan berbagai cara dalam menyampaikan materi Matematika agar lebih mudah dimengerti dan bermakna bagi siswa.

Pendidikan di Indonesia mengharapkan terjadinya keberhasilan dalam proses serta hasil pembelajaran, termasuk pada pembelajaran Matematika. Keberhasilan yang dimaksud yakni siswa mengalami proses pembelajaran yang menyenangkan, inovatif, dan efektif. Namun, sayang sekali, kenyataan menunjukkan bahwa mata pelajaran Matematika tidak begitu diminati oleh para siswa di sekolah, dan banyak persepsi tentang Matematika merupakan pelajaran yang sulit dan membosankan baik di Sekolah Dasar maupun lanjutan. Kurangnya pengalaman langsung siswa serta materi yang begitu sulit cenderung membuat siswa merasa jenuh.

Beberapa masalah teridentifikasi berdasarkan wawancara yang telah dilakukan pada guru mata pelajaran Matematika yang sekaligus merupakan wali kelas V SD Negeri 4 Kampung Baru Tanggal 6 Pebruari 2018 pukul 07.30-10.30. Kaitannya dengan seluruh kegiatan yang berkaitan dengan pembelajaran, guru menyimpulkan bahwa Matematika merupakan mata pelajaran yang paling sulit untuk diajarkan pada siswa. Hal tersebut didukung oleh hasil observasi yang menunjukkan kurangnya motivasi dan aktivitas siswa dalam porses pembelajaran Matematika dikarenakan guru cenderung meggunakan cara belajar konvensional, pembelajaran didominasi oleh guru, sedangkan siswa hanya berperan sebagai penerima konsep atau materi dari guru. Permasalahan-permasalah dalam proses pembelajaran tersebut akhirnya berdampak pada rendahnya hasil belajar siswa terlihat perolehan nilai rata-rata kelas yakni 68,3. Dari 46 siswa kelas $\mathrm{V}$ tersebut, 24 diantaranya belum mencapai KKM yang ditentukan yakni 75. Jadi ketuntasan klasikalnya hanya mencapai $48 \%$ atau bejumlah 22 siswa.

Berdasarkan permasalahan tersebut, tentu saja menjadi tanggung jawab dan kewajiban guru untuk menyelesaikan masalah-masalah belajar para peserta didiknya. Karena pada dasarnya permasalahan ini dapat diselesaikan dengan mengembangkan alternatif pemecahan masalah yang afektif untuk mengatasi masalah dalam pembelajaran yakni dengan menerapkan model pembelajaran yang tepat, yang dapat meningkatkan motivasi belajar siswa. Sehingga pembelajaran menjadi lebih bermakna, tidak hanya memberi pengetahuan akademik pada siswa melainkan juga dapat mengajarkan siswa akan pentingnya sikap kerjasama dalam sebuah kompetisi.

Salah satu model pembelajaran yang dapat digunakan untuk mengatasi rendahnya hasil belajar matematika siswa yaitu model pembelajaran Problem Solving. Model Problem Solving yaitu model pembelajaran yang orientasinya adalah melatih siswa dalam memecahkan 
masalah. Model ini dapat diterapkan pada pembelajaran Matematika, mengingat dalam Matematika siswa sering dihadapkan pada permaslahan-permasalahan yang dikembangkan dari konsep Matematika. Selain itu, Matematika juga dapat digunakan dalam menyelesaikan masalah yang terkait dengan aktivitas sehari-hari. Dalam aplikasinya dibutuhkan kemampuan untuk menerapkan konsep-konsep Matematika ke dalam situasi yang berbeda, hingga dapat diterjemahkan kembali dalam bentuk masalah Matematika dan dicari penyelesaiannya. Hal ini akan membuat siswa memahami manfaat dari belajar Matematika. Melalui penerapan Problem Solving akan dapat mengembangkan kekemampuan berpikir rasional siswa, yaitu kemampuan menganalisis situasi, menerapkan kemampuan yang mereka miliki dalam situasi baru, kemampuan siswa untuk memecahkan masalah, serta memahami hubungan anta apa yang dipelajari dengan kenyataan dalam kehidupannya (Sanjaya, 2006: 214).

Berdassarkan uraian di atas, penelitian ini bertujuan untuk untuk mengetahui peningkatan yang terjadi pada hasil belajar Matematika siswa kelas V SD Negeri 4 Kampung Baru setelah penerapan model pembelajaran Problem Solving dalam pembelajaran..

Peneliti menganggap model Problem Solving adalah model pembelajaran yang cocok untuk menyelesaikan masalah hasil belajar matematika di SDN 4 Kampung Baru. Oleh karena itu, peneliti ingin mengadakan penelitian tindakan kelas dengan cara menerapkan model pembelajaran kontekstual untuk meningkatkan hasil belajar matematika siswa kelas 5 di SDN 4 Kampung Baru .

\section{Metode}

Sebagaimana dijelaskan di atas, model pembelajaran yang digunakan dlam penelitian ini yakni Problem Solving

Strategi pembelajaran dengan Problem Solving dapat diterapkan:

Manakala guru menginginkan agar siswa tidak hanya sekedar dapat mengingat materi pelajaran, akan tetapi menguasai dan memahaminya secara penuh sehingga dapat diaplikasikan untuk membantu kegiatan sehari-hari, yang tentunya terkait konsep/ materi tersebut, apabila guru bermaksud untuk mengembangkan keterampilan berpikir rasional siswa, yaitu kemampuan menganalisis situasi, menerapkan pengetahuan yang mereka miliki dalam situasi baru, mengenal adanya perbedaan antara fakta dan pendapat, serta mengembangkan kemampuan peserta didik dalam memberi penilaian (judgment) yang objektif, manakala guru menginginkan kemampuan siswa untuk memecahkan masalah serta membuat tantangan intelektual siswa, manakala guru ingin siswa memiliki rasa tanggung jawab dalam proses pembelajaran, manakala guru ingin agar siswa memahami keterkaitan atau hubungan antara apa yang dipelajari dengan kenyataan dalam kehidupan sehari-hari (hubungan antara teori dengan kenyataan).

Konsep-konsep Matematika sangat erat kaitannya dengan pemecahan masalah dalam kehidupan sehari-hari. Inilah yang seharusnya menjadi dasar pertimbangan para pendidik untuk menggunakan model Problem Solving dalam proses pembelajaran Matematika.

Adapun langkah dalam melakukan dalam melakukan pemecahan masalah, antara lain yang pertama yakni memahami masalah (understand the problem).Meupakam langkah utama atau awal dalam menyelesaikan masalah. Tanpa mengetahui permasalahan terlebih dahulu, maka dapat dipastikan kita tidak akan mungkin mengetahui bagaimana menghadapi masalah tersebut. Memahami masalah dalam menyelesaikan masalah dapat dilakukan dengan mengajukan beberapa pertanyaan terkait dengan masalah tersebut, diantaranya apa yang diketahui dari soal, apa saja informasi yang diperlukan, dan bagaimana menyelesaikan soal tersebut, serta kemungkinan-kemungkinan pertanyaan-pertanyaan lain yang mengarah pada 
pemahaman tentang masalah yang ada. Langkah kedua yakni membuat rencana penyelesaian masalah (devise a plan). Menyelesaikan permasalah yang dipahami tidak akan berjalan dengan baik jika proses penyelesaiannya tidak direncanakan dengan baik pula. Dalam membuat rencana penyelesaian masalah, kegiatan kita diarahkan kepada pemilihan strategistrategi yang tepat untuk menyelesaikan masalah. Dengan demikian, dalam melakukan perencanaan atau mengidenifikasi strategi tersebut hendaknya berkaitan dengan permasalahan yang akan dipecahkan. Langkah ketiga yakni melaksanakan rencana yang telah ditetapkan (carry out the plan) setelah tahap memahami permasalahan dan penentuan strategi penyelesaian masalah telah dilakukan, langkah berikutnya adalah melaksanakan penyelesaian soal sesuai dengan rencana yang telah ditetapkan. dalam hal ini, kemampuan peserta didik dalam memahami substansi materi dan keterampilan peserta didik melakukan perhitunganperhitungan Matematika akan sangat membantu peserta didik untuk melakukan rencana penyelesaian masalah. Langkah keempat yakni memeriksa ulang jawaban yang diperoleh (look back at the completed solution). Memeriksa ulang jawaban yang diperoleh merupakan penentuan dari beberapa tahapan yang telah dilakukan dalam Problem Solving. Hal tersebut dikarenakan, memeriksa ulang jawaban dilakukan untuk mengetahui apakah jawaban yang kita peroleh sudah sesuai dengan ketentuan yang ada. langkah ini juga akan menentukan apakah hasil penyelesaian yang kita dapatkan dapat diterima sebagai penyelesaian masalah, atau dilakukan penyelesaian kembali karena terdapat beberapa hal yang keliru sehingga jawabannya tidak dapat dipertanggung jawabkan.

Keempat langkah tersebut merupakan penyelesaian masalah yang paling sering digunakan dalam penyelesaian masalah matematika, sehingga dalam pengembangan pedoman pembelajaran matematika yang akan dilakukan dalam penelitian ini, mengikuti proses penyelesaian masalah sebagaimana yang dikemukakan di atas.

Metode yang digunakan dalam penelitian ini yaitu Penelitian Tindakan Kelas (PTK) karena Penelitian Tindakan Kelas bertujuan untuk mengatasi dan memperbaiki berbagai permasalahan yang terjadi di dalam kelas, yaitu mengenai proses belajar mengajar dan prestasi belajar siswa. Dengan melaksanakan tahapan-tahapan dalam PTK, guru mampu memperbaiki proses pembelajaran melalui suatu kajian yang dalam terhadap apa yang terjadi di kelasnya, tindakan yang dilakukan guru semata-mata didasarkan pada masalah yang berkembang di kelasnya (Zainal Aqib, 2006:13-14).

Penelitian ini dilakasanakan dalam bentuk siklutis, yakni pelaksanaan siklus berikutnya sangat dipegaruhi oleh siklus sebelumnya, dengan kata lain seiap siklus dalam peneitian saling terkait dan berkesinambungan hingga diperoleh hasil yang ingin dicapai.

Setiap siklus dilaksanakan dalam 2 kali pertemuan. Hal ini berdasarkan alokasi waktu pelajaran Matematika kelas V semester II di SD Negeri 4 Kampung Baru yaitu 2 kali pertemuan dalam 1 minggu, masing-masing pertemuan mempunyai alokasi waktu $3 \times 35$ menit, serta disesuaikan pula dengan tingkat ketercapaian tujuan yang diharapkan dan rincian indikator yang diteliti. Masing-masing siklus di lakukan dalam 4 tahap yaitu (1) Tahap perencanaan tindakan; (2) Tahap pelaksanaan tindakan; (3) Tahap evaluasi; (4)Tahap Refleksi. 
Berikut merupakan siklus kegiatan PTK.

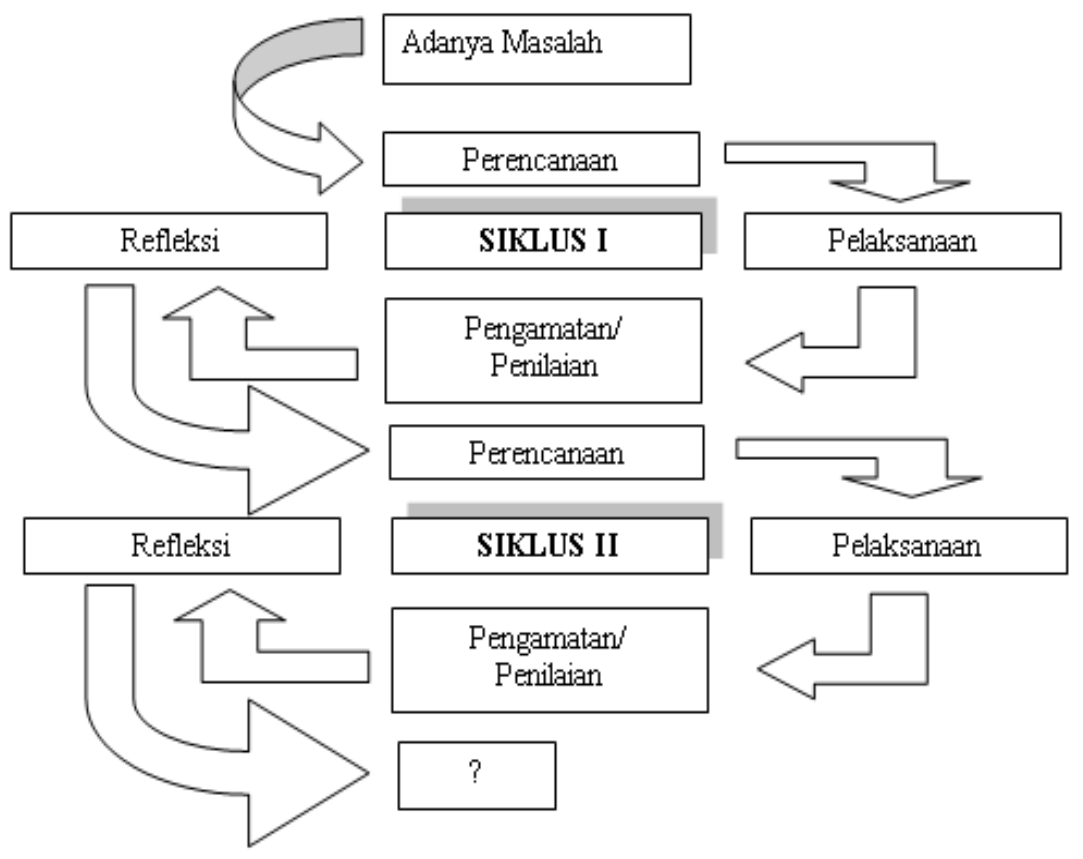

Gambar 3.1 Rancangan Penelitian Tindakan Kelas Arikunto 2010: 137

Sesuai dengan rancangan penelitian yang direncanakan, maka langkah-langkah penelitian yang dilalui sebagai berikut :

Siklus 1 diawali dengan tahap perencanaan tindakan Perencanaan merupakan tahap awal yang dilakukan peneliti. Kegiatan yang dilaksanakan pada tahap ini adalah (1) Membuat skenario pembelajaran (RPP). (2) Menyiapkan media konkret yang menunjang; (3) Membuat lembar kerja peserta dididk (LKPD); (4)Menyiapkan materi dan merancang media pembelajaran yang sesuai dengan materi dalam pelaksanaan model pembelajaran Problem Solving; (5) Membuat lembar observasi aktivitas guru; (6) Membuat lembar observasi aktivitas siswa. (7) Membuat alat evaluasi untuk mengukur kemampuan siswa yang berupa soal latihan.

Berikutnya yakni pelaksanaan tindakan. Dalam tahap ini peneliti berperan sebagai pengajar dan pengumpul data. Hal yang dilakukan pada tahap pelaksanaan tindakan ini yaitu melaksanakan kegiatan belajar mengajar di kelas sesuai dengan rencana yang telah dituangkan dalam skenario pembelajaran. Kegiatan yang dilaksanakan pada tahap ini adalah pelaksanaan tindakan dengan menggunakan model Problem Solving pada mata pelajaran Matematika kelas V SD Negeri 4 Kampung Baru untuk melihat perolehan pemahaman siswa kaitannya dengan pembelajaran. Tahap pelaksanaan tindakan yang dilakukan yakni kegiatan awal, kegiatan inti, dan penutup. Dalam kegiatan awal, guru mengkondisikan siswa untuk siap mengikuti proses pembelajaran. Adapun kegiatan-kegiatan yang dilakukan pada tahap ini antara lain (1) Guru mengecek kehadiran siswa dan menyapa siswa; (2) Siswa menyimak informasi dari guru terkait materi yang akan dielajari, dan tujuan pembelajaran; (3) Melakukan apersepsi yang berhubungan dengan materi pelajaran yakni statistika untuk memberikan motivasi. Apersepsi ini mengikuti tahapan-tahapan Model pembelajaran Problem Solving. Berikutnya pada kegiatan inti ini diharapkan proses pembelajan bermakna dirasakan oleh siswa, sehingga guru merencanakan kegiatan-kegatan yang dilaksanakan pada kegiatan inti ini antara lain (1) Siswa membentuk kelompok; (2) Setiap kelompok mengambil lembar kerja berisi masalah yang harus diselesaikan; (3) Siswa diarahkan untuk memecahkan permasalahan secara berkelompok sesuai prosedur model Problem Solving, yakni menganalisis masalah, menyusun sebuah rencana penyelesaian masalah, melaksanakan pemecahan masalah sesuai 
rencana yang telah dibuat, serta memeriksa ulang hasil pemecahan masalah; (4) Tiap perwakilan kelompok menjelaskan penyelesaian masalah yang telah dibuatnya dengan tujuan untuk melihat kembali hasil akhir dan membahasnya bersama-sama; (5) Siswa lain diberikan kesempatan siswa untuk bertanya atau berpendapat; (6) Siswa menjawab atau menanggapi pertanyaan atau pendapat temannya. Terakhir yakni kegiatan penutup. Berkenaan dengan kegiatan guru dan siswa sebelum mengakhiri proses pembeajaran. Kegiatan-kegiatan tersebut anatara lain (1) Siswa bersama dengan guru menyimpulkan hasil seluruh rangkaian pembelajaran pembelajaran. (2) Siswa melakukan refleksi terhadap kegiatan yang telah dilaksanakan. (3) Siswa mengerjakan soal evaluasi yang diberikan guru. (4) Guru dan siswa berdoa bersama dan mengucapkan salam penutup.

Tahap selanjutnya yakni evaluasi. Merupakan tahapan penelitian yang bertujuan untuk menggetahui hasil belajar siswa setelah pelaksanaan pembelajaran. Evaluasi dilakukan setiap akhir siklus. Berdasarkan evaluasi ini kemudian dipertimbangkan mengenai perlu atau tidaknya pengadaan siklus berikutnya.

Setelah evaluasi dilakukan, Tahap berikutnya yakni Refleksi. Tahap refleksi dilakukan pada akhir siklus, pada tahap ini peneliti bersama guru mengkaji pelaksanaan dan hasil yang diperoleh dalam pemberian tindakan tiap siklusnya. Sebagai acuan dalam refleksi ini adalah hasil evaluasi. Hasil ini digunakan sebagai dasar untuk memperbaiki serta menyempurnakan perencanaan dan pelaksanaan tindakan pada siklus selanjutnya.

Jika keseluruhan tahap penelitian telah dilaksanakan, yang harus dilakukan yakni penyimpulan perlu atau tidaknya dilaksanakan siklus lanjutan. Apabila hasil evaluasi telah mencapai kriteria keberhasilan penelitian yang telah ditentukan maka penelitian tindakan kelas dihentikan. Sebaliknya apabila hasil evaluasi belum mencapai kriteria keberhasilan, maka perlu untuk diadakan perbaikan pada siklus berikutnya. Langkah-langkah yang dilakukan pada siklus lanjutan atau siklus berikutnya pada prinsipnya sama dengan siklus I, tetapi pada siklus ini bertujuan untuk memperbaiki kekurangan-kekurangan pada tindakan siklus sebelumnya.

Penelitian ini dilaksanakan di kelas V SDN 4 Kampung Baru Kelurahan Kampung Baru Kecamatan Buleleng pada tanggal 5 sampai 13 April 2018. Pelaksanaan kegiatan tiap siklus penelitian ini dialokasikan dua kali pertemuan. Subjek penelitian ini adalah siswa kelas 5 SDN 4 Kampung Baru yang bberjumlah 46 orang, terdiri dari 21 orang laki-laki dan 25 perempuan. Objek penelitian ini adalah hasil belajar matematika siswa kelas V SD Negeri 4 Kampung Baru.

Dalam Penelitian ini, hasil belajar yang dimaksud adalah nilai mata pelajaran matematika yang didapat siswa kelas 5 SDN 4 Kaliuntu setelah diadakannya evaluasi. Model pembelajaran kontekstual adalah konsep belajar yang membantu guru mengkaitkan antara materi yang diajarkanya dengan situasi dunia nyata siswa dan mendorong siswa membuat hubungan antara pengetahuan yang dimilikinya dengan penerapan dalam kehidupan sehari-hari. Siswa diajak aktif menkonstruksi dan menemukan sendiri konsep yang dipelajari.

Metode pengumpulan data yang digunakan dalam penelitian adalah metode tes. Tes tersebut merupakan tes tuls berupa soal pilihan ganda dan uraian yang akan dilaksanakan tiap akhir siklus untuk mengetahui peningkatan hasil belajar siswa setelah diterapkannya model pembelajaran Problem Solving.

Analisis data dalam penelitian ini menggunakan teknik analisis kuantitatif. Analisis data kuantitatif digunakan untuk menganalisa data kuantitatif, seperti hasil tes evaluasi. Adapun langkah-langkah dalam melakukan analisis data kuantitatif tersebut antara lain:

a. Menghitung Nilai Individu

Menghitung nilai individu siswa dapat menggunakan rumus sebagai berikut: 
$N A=\frac{S P}{S M} \times 100($ Kunandar, 2013)

NA $=$ Nilai Akhir

SA = Skor Perolehan

$\mathrm{SM}=$ Skor Maksimal

Untuk memudahkan pengamatan dan proses penentuan rata-rata kelas, maka dilakukan tabulasi nilai individu seluruh siswa kelas V sebagai berikut.

Tabel 3.2 Tabulasi Nilai Siswa Kelas V

\begin{tabular}{|c|c|c|c|c|}
\hline No & Kode Siswa & Nilai Akhir & KKM & Keterangan \\
\hline \multicolumn{5}{|l|}{1} \\
\hline \multicolumn{5}{|l|}{2} \\
\hline \multicolumn{5}{|l|}{3} \\
\hline \multicolumn{5}{|l|}{4} \\
\hline \multicolumn{5}{|l|}{$\cdot$} \\
\hline 46 & & & & \\
\hline
\end{tabular}

Jumlah Nilai $\left(\sum X\right)$

Selanjutnya nilai presentase ketuntasan belajar siswa yang di dapat dengan rumus di atas selanjutnya ditafsirkan berdasarkan tabel berikut ini.

Tabel 3.3 Kriteria Tingkat Keberhasilan Siswa dalam \%

\begin{tabular}{ll}
\hline \multicolumn{1}{c}{ Tingkat keberhasilan (\%) } & \multicolumn{1}{c}{ Kategori } \\
\hline $90-100$ & Sangat Baik \\
\hline $80-89$ & Baik \\
\hline $65-79$ & Cukup \\
\hline $55-64$ & Kurang \\
\hline $0-54$ & Sangat rendah \\
\hline
\end{tabular}

(Sumber: Agung, 2010:58)

Menghitung nilai rata-rata siswa dapat dilakukan dengan menggunakan rumus:

$$
\begin{array}{ll}
\bar{X} & =\frac{\sum X}{N} \text { (Sudjana, 2012: 109) } \\
\bar{X} & =\text { rata-rata } \\
\sum_{N} X & =\text { jumlah seluruh nilai } \\
& =\text { banyaknya subjek }
\end{array}
$$

Menghitung ketuntasan klasikal dapat dilakukan dengan menggunakan rumus:

$K B=\frac{P}{N} \times 100 \%$ (Nurkencana dan Sunarta (1990))

Keterangan: 
$\mathrm{KB}=$ Ketuntasan Belajar

$\mathrm{P}=$ Banyak siswa yang memproleh nilai di atas $\mathrm{KKM}$

$\mathrm{N}$ = Banyak seluruh siswa yang mengikuti tes.

\section{Pembahasan}

Berdasarkan penelitian yang dilakukan, berikut merupakan tabel ringkasan hasil evaluasi dalam dua siklus.

Tabel 4.3 Perbandingan hasil evaluasi siklus I dan siklus II

\begin{tabular}{ccccc}
\hline \multirow{2}{*}{ Siklus } & \multicolumn{4}{c}{ Hasil Belajar } \\
\cline { 2 - 5 } & $\begin{array}{c}\text { Jumlah siswa } \\
\text { tuntas }\end{array}$ & $\begin{array}{c}\text { Jumlah siswa } \\
\text { belum tuntas }\end{array}$ & $\begin{array}{c}\text { Rata-rata } \\
\text { kelas }\end{array}$ & Ketuntasan klasikal \\
\hline $\mathbf{1}$ & 34 & 12 & 73,69 & $73,91 \%$ \\
\hline $\mathbf{2}$ & 39 & 7 & 80,22 & $84,78 \%$ \\
\hline
\end{tabular}

Berdasarkan hasil ringkasan hasil evaluasi siswa, terjadi peningkatan hasil belajar siswa yang dapat dilihat dari hasil evaluasi siswa siklus 1 dan siklus 2. Berdasarkan data yang diperoleh dari siklus I menunjukkan bahwa kriteria keberhasilah yang ditetapkan belum tercapai, karena meskipun rata-rata kelas melebihi KKM yang ditetapkan, namun ketuntasan belajar secara klasikal yang dicapai siswa pada siklus I hanya $73,69 \%$ atau berkategori cukup sedangkan ketuntasan belajar dapat dikatakan tercapai jika ketuntasan hasil belajar siswa minimal mencapai $80 \%$ atau berkategori baik. Hal ini disebabkan adanya kekurangankeurangan dalam pelaksanaan proses pembelajaran kaitannya dengan penerapan model pembelajaran Problem Solving.

Berdasarkan pelaksanaan pembelaajaran, dirasakan beberapa kekurangan-kekurangan yang terjadi pada tiap siklusnya. Adapun kekurangan yang terjadi pada siklus 1 , diantaranya intraksi guru dan siswa masih kurang, hal ini karena siswa masih malu dan belum mempersiapakan diri untuk mengikuti pembelajaran serta belum beradaptasi dengan guru baru. Selain itu guru kurang mampu dalam menguasai kelas.

Dalam kegiatan diskusi, guru kurang memberikan gambaran yang jelas tentang apa yang harus dilakukan oleh siswa karena guru menduga mereka sudah memahami petunjuk umum yang disampaikan guru. Akibatnya ada kelompok yang kurang memahami pengerjaan LKPD. Cara penyampaian guru pada saat memberikan penjelasan mengenai materi maupun arahan pengerjaan tuga kelompok juga terlalu cepat. Di samping itu, guru juga kurang mampu kaitannya dengan manajemen waktu untuk tiap-tiap tahap pembelajaran.

Berdasarkan kekurangan-kekurangan tersebut, maka dilakukan tindakan perbaikan yang akan dilakukan pada siklus 2. Adapun tindakan perbaikan yang akan dilaksanakan, diantaranya memberikan apersepsi dan memotivasi siswa agar tidak malu mengungkapkan pendapat atau pertanyaan kepada guru mengenai hal-hal yang belum dimengerti, melakukan tanya jawab mengenai materi prasyarat dalam pembelajaran dan konsep-konsep penting yang menunjang kegiatan diskusi serta guru melakukan identifikasi permasalahan tiap-tiap kelompok kemudiamn memberikan bimbingan atau penjelasan di waktu yang bersamaan untuk keseluruhan kelompok, serta, serta menghimbau dan memberikan kesempatan kepada siswa 
untuk menyimpulkan materi.

Pada siklus 2 terjadi peningkatan terhadap nilai rata-rata kelas dan ketuntasan belajar siswa secara klasikal. Niai rata-rata kelas siswa pada siklus II ini yakni 80,22 dan ketuntasan belajar siswa secara klasikal yakni $84,78 \%$ Dengan demikian tujuan yang diinginkan pada indikator kerja sudah tecapai yaitu rata-rata kelas siswa lebih dari KKM yang ditetapkan yakni 70 , dan ketuntasan belajar lebih dari $80 \%$ atau berkategori baik.

Pembelajaran Problem solving ini dikembangkan untuk melatih siswa untuk dapat berpikir kritis, analitis, simpatis, dan logis guna menemukan alternatif pemecahan masalah melalui eksplorasi data secara empiris dalam rangka menumbuhkan sikap ilmiah (Sanjaya, 2006: 216).

Model Problem Solving merupakan model pembelajaran yang menghadapkan siswa pada suatu permasalahan, siswa kemudian dibimbing untuk mampu memahami masalah tersebut, merencanakan pemecahan masalah, melaksanakan pemecahan mesalah, hingga memeriksa ulang jawaban yang diharapkan sebagai alternatif pemecahan atas masalah tersebut.

Pembelajaran dengan model Problem Solving diawali guru membagi siswa menjadi 64 kelompok yang beranggotakan 6-7 orang siswa, kemudian kelompok tersebut dihadapkan pada suatu permasalahan dalam bentuk lembar kerja (LKPD) untuk dikerjakan secara berkelompok sesuai tahapan-tahapan Problem Solving, dimana siswa memahami masalah, menyusun perencanaan pemecahan masalah, melaksanakan perencanaan pemecahan masalah, memeriksa kembali jawaban, hingga presentasi oleh perwakilan tiap-tiap kelompok.

Berdasarkan data-data yang diperoleh dari penelitian tersebut, maka dapat disimpulkan bahwa penerapan metode Problem solving dapat meningkatkan hasil belajar siswa dalam pelajaran Matematika kelas V SD Negeri 4 Kampung Baru Tahun 2017/ 2018.

\section{Simpulan dan Saran}

Berdasarkan hasil penelitian yang telah dilaksanakan, dapat disimpulkan bahwa terjadi peningkatan terhadap hasil belajar siswa. Hal ini dapat dilihat dari hasil evaluasi siklus I dan II yang diperoleh siswa, yakni dengan perolehan nilai rata-rata 73,69 pada siklus I, kemudian mengalami peningkatan menjadi 80,22 pada siklus II. Begitu pun pada ketuntasan belajar siswa secara klasikal, mengalami peningkatan dari $73,31 \%$ pada siklus 1 menjadi $84,78 \%$ pada siklus 2. Berdasarkan hasil tersebut, maka dapat disimpulkan bahwa penerapan model Problem Solving dapat meningkatkan hasil belajar Matematika siswa SDN 4 Kampug Baru tahun pelajaran 2017/ 2018.

Adapun saran yang ingin disampaikan dari hasil penelitian ini adalah sebagai berikut: (1) Kepada siswa diharapkan lebih aktif dalam kegiatan pembelajaran agar konsep pembelajaran dapat lebih mudah dipahami sehingga dalam mengerjakan tugas atau soal lebih mudah dikerjakan. (2) Kepada guru diharapkan untuk dapat menerapkan metode pembelajaran Problem Solving dalam melaksanakan proses pembelajaran untuk meningkatkan hasil belajar siswa. (3) Kepada kepala sekolah diharapkan dapat memberikan bimbingan kepada dewan guru untukmpenggunakan model pembelajaran Problem Solving dalam kegiatan pembelajaran sebagai upaya untuk meningkatkan kualitas pendidikan di sekolah. (4) Kepada peneliti lain, agar dapat menggunakan penelitian ini sebagai bahan referensi tambahan dalam melaksanakan penelitian terkait penggunaan model pembelajaran Problem Solving. 


\section{Daftar Pustaka}

Agung, A.A. Gede. 2010. Metode Penelitian Pendidikan. Singaraja: Universitas Pendidikan Ganesha.

Alkusaeri, Irzami. 2013. Pengembangan Program Pembelajaran Matematika. Banjarnegara: Sukses Mandiri Press.

Arikunto, Suharsimi. 2010. Penelitian Tindakan Kelas. Jakarta: Bumi Aksara.

Aqib, Zainal. 2006. Penelitian Tindakan Kelas untuk Guru. Bandung: Yrama Widya.

Fitriana, Baiq Intan. 2013. Penerapan Model Problem Solving Untuk Meningkatkan Hasil Belajar PknMateri Globalisasi Siswa Kelas IV SD Negeri 9 Sepit Tahun Pelajaran 2012/2013. Mataram: Universitas Mataram.

Heruman. 2007. Model Pembelajaran Matematika di Sekolah Dasar. Bandung: PT Remaja Rosdakarya.

Hudojo, Herman. 1990. Strategi Belajar Mengajar Matematika. Malang: IKIP Malang.

Jihad, Asep dan Haris, Abdul. 2008. Evaluasi Pembelajaran. Yogyakarta: Multi Pressindo.

Karso, dkk. 2007. Pendidikan Matematika. Banten. Universitas Terbuka.

Kunandar. 2013. Penilaian Autentik. Jakarta. PT Raja Grafindo Persada.

Mulyono. 2011. Strategi Pembelajaran. Malang: UIN Maliki Press.

Nurbay. 2005. Penerapan Model Pemecahan Masalah Pada Pembelajaran Matematika Pokok Bahasan Teorema Phitagoras di Smp Negeri 8 Mataram Kelas II-A Tahun Ajaran 2004/ 2005.Mataram: Tidak diterbitkan.

Nurkancana, W dan Sumartana, P.P.N. 1986. Evaluasi Pendidikan. Surabaya: Usaha Bersama.

Sanjaya, Wina. 2006. Strategi Pembelajaran Berorientasi Standar Proses Pendidikan. Jakarta: Prenadamedia Group.

Slameto. 2010. Belajar dan Faktor-faktor yang Mempengaruhinya. Jakarta: Rineka Cipta.

Sudjana, Nana. 1987. Dasar-dasar Proses Belajar Mengajar. Bandung: Sinar Baru Algensindo.

Sudjana, Nana. 2009. Penilaian Hasil Proses Belajar Mengajar. Bandung: PT. Remaja Rosda Karya.

Runtukahu, Tombokan dan Kandou, Selpius. 2013. Pembelajaran Matematika Dasar bagi Anak Berkesulitan Belajar. Yogyakarta: Ar-Ruzz Media.

Widiada, Ketut, dkk. 2010. Pedoman Penulisan Skripsi. Mataram: Universitas Mataram. 